\title{
Lean MANUfaCturing in SLOVEnian COMPANIES
}

\section{VujicA HERZOG, N. \& BuCHMEISTER, B.}

Abstract: The paper presents the results from a survey research performed in 72 medium and large-sized Slovenian manufacturing companies within mechanical and electro-mechanical industries. Nine crucial areas about 'lean' were identified based on a synthesis of literature review: value concepts, value stream mapping (VSM), kanban, flow, waste elimination, maintenance, customers, JIT, employee cooperation, development of excellent suppliers and lean design. For these nine areas questionnaire was designed and sent to general managers or managers responsible for lean projects. Survey research results are presented using descriptive statistics analysis for all nine critical areas. The results exposed the most important topics that should be practiced for effective lean manufacturing.

Key words: lean, lean manufacturing, lean thinking, survey research
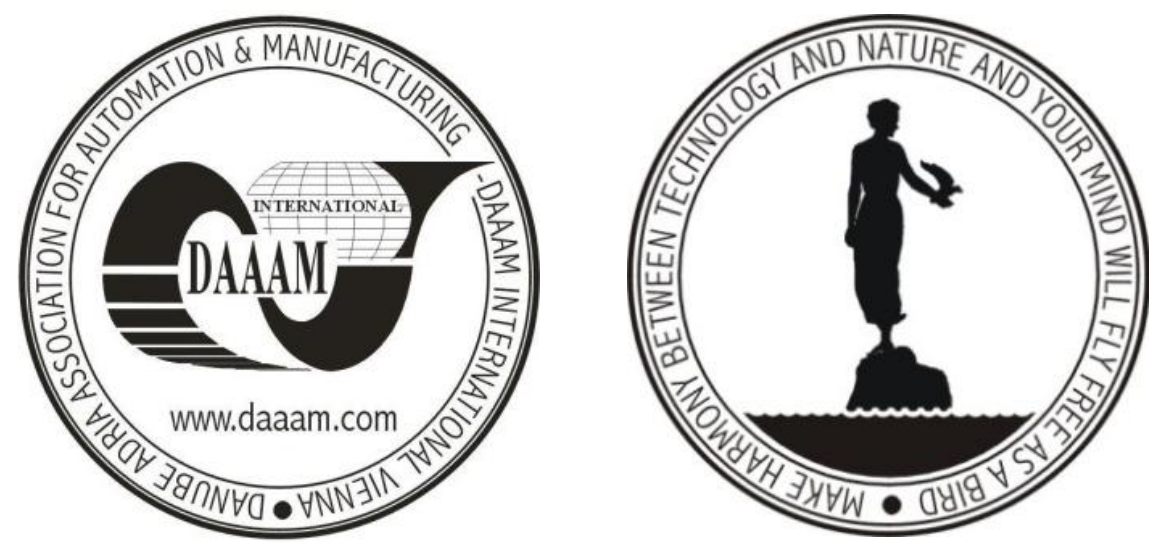

Authors' data: Asist. Prof. Dr. Sc. Vujica Herzog, N[atasa]; Assoc. Prof. Dr. Sc. Buchmeister, B[orut]; University of Maribor, Faculty of Mechanical Engineering, Smetanova ulica 17, 2000, Maribor, Slovenia, natasa.vujica@uni-mb.si, borut.buchmeiste@uni-mbs.i

This Publication has to be referred as: Vujica Herzog, N[atasa] \& Buchmeister, B[orut] (2012). Lean Manufacturing in Slovenian Companies, Chapter 11 in DAAAM International Scientific Book 2012, pp. 117-128, B. Katalinic (Ed.), Published by DAAAM International, ISBN 978-3-901509-86-5, ISSN 1726-9687, Vienna, Austria DOI: $10.2507 /$ daaam.scibook.2012.11 
Vujica Herzog, N. \& Buchmeister, B.: Lean Manufacturing in Slovenian Compani...

\section{Introduction}

Lean manufacturing (LM) is a system or methodology developed in Japan after Second World War. It is a conceptual framework popularized in many Western industrial companies since the early 1990s. One of the main goals of lean manufacturing is the elimination of everything that does not add value to the product or service (Womack \& Jones, 1996; Dirgo, 2006). There are several common lean production principles found in the literature. One of the main concepts of Toyota Production System (TPS) is just-in-time (JIT). To maintain JIT production in Toyota plants, Ohno (1988) devised Kanban as a means to pull material from an upstream station and manage product flow. In describing and measuring JIT, Sugimori at al. (1977) also focused on its most critical components such as Kanban, production smoothing, and set up time reduction. Later definitions incorporate these elements but also include quality improvement and employee involvement (Hall, 1987) and customers focus (Flynn et all, 1995, Nicholas, 1998). Inventories are one of the main sources of inefficiency in industrial companies. Generally, the storage does not add value to the product and it should be eliminated whenever possible. Nine crucial areas about 'lean' were identified based on a synthesis of literature review: value concepts, value stream mapping (VSM), kanban, flow, waste elimination, maintenance, customers, JIT, employee cooperation, development of excellent suppliers and lean design.

The main purpose of the presented paper is its contribution to better understanding of lean concepts. Since most of the literature is based on case studies, survey research can be of a great importance for further theory building and development. The survey research was limited to Slovenian companies and performed in 72 medium and large-sized manufacturing companies within mechanical and electro-mechanical industries. Other industries and services were not included in research. For nine crucial areas defined from the literature review descriptive statistics results are presented showing the most important topics from lean that should be practiced for effective lean manufacturing.

\section{Literature review}

The concept of Lean was developed by the Toyota executive Taiichi Ohno in Japan. In 1973 Oil crisis hits North America and generates immense interest in the new Japanese manufacturing and management practices followed by publication of numerous academic and practitioner books and articles. In the early 80's, several Japanese manufacturers built plants in the US and operated them with lean principles. The success of these plants proved that Lean was not just a Japanese cultural phenomenon, but could be successful outside the Japan. According to Ohno, the primary goal of Toyota Production System (TPS) is cost reduction - waste elimination. It can be achieved through quantity control, quality assurance, and respect for humanity. He recommends producing only the kind of units needed, at the time needed and in the quantities needed.

In 1990 The machine that changed the world by Womack, Jones and Roos is published. The machine establishes 'lean production' to characterize Toyota's 
production system including its underlying components in the popular lexicon. The term 'lean', describing the manufacturing system used by Toyota was coined by Krafcik (1988). The book The machine that changed the world describes a lean system in detail and in 1994 Womack and Jones published another book where the lean philosophy is extended and the guiding principles underlying lean to an enterprise level are presented. Since that time numerous books and articles were written by practitioners, consultants and academics about lean.

Lean manufacturing is generally described from two points of view, either from a philosophical perspective related to guiding principles and overarching goals (Shah \& Ward; 2007; Womack \& Jones, 1996; Spear \& Bowen, 1999), or from the practical perspective of a set of management practices, tools, or techniques that can be observed directly (Shah \& Ward, 2003). We will briefly discuss both points of view, although it is obviously that for effective lean implementation both views are present and connected.

Starting from the practical perspective view we will first inspect the basic principles that characterise a lean enterprise. According to James P. Womack and Daniel T. Jones (1996) the basic characteristics can be summarized into a set of five basic principles:

- Define 'value' from the perspective of the customer.

- Identify the 'value streams' and eliminate 'waste' from them.

- Create 'Pull'.

- Introduce 'Pull'.

- Strive to 'Perfection'.

The basic principle of lean is responsiveness to change and waste minimization. For this reason management should focus on each product and its value stream rather than organizations, assets technologies, and career paths (Motwani, 2003). They should identify which activities are waste and which truly create value. Their goal should be to enhance the value and eliminate waste. Womack and Jones suggest that, if managers apply these concepts collectively, they can reap full benefit of lean techniques and significantly improve their product's competitive edge. Lean identifies seven types of waste:

1. Over-Production; obviously a product that cannot be sold or has to be dumped at a reduced price is wasteful. Also producing product before the customer needs it requires the part to be stored and ties up money and inventory.

2. Inventory; excess Inventory ties up a great deal of cash, which is wasteful. Stockpiling inventory between processes is wasteful.

3. Conveyance; unnecessarily moving a part during the production process is wasteful. It can also cause damage to the part, which creates wasteful rework.

4. Correction; having to re-work parts because of manufacturing errors is a large source of waste. Additionally, sorting and inspecting parts is wasteful and can be eliminated by error proofing (designing your processes so that the product can only be produced one way, which is the correct way, every time).

5. Motion; unnecessary or awkward operator motions put undue stress on the body and cause waste. Improvement in this area should result in reduced injury and workman's compensation claims. 
Vujica Herzog, N. \& Buchmeister, B.: Lean Manufacturing in Slovenian Compani...

6. Processing; unclear customer requirements cause the manufacturer to add unnecessary processes, which add cost to the product.

7. Waiting; the operator being idle between operations is wasteful. It is acceptable for the machine to wait on the operator, but it is unacceptable for the operator to wait on the machine.

To see and eliminate waste in the work environment requires a major shift in one's understanding as to what waste is. The old definition of waste is usually described as scrap and rework. To truly implement a Lean Manufacturing System we must first change the definition of waste to anything that does not add value to the customer. Once we changed our mindset, we will see a lot of opportunities for eliminating waste.

There are many tools available for achieving lean manufacturing. These include:

- Cellular manufacturing: Organizes the entire process for a particular product or similar products into a group or cell, including all the necessary machines, equipment and operators. Resources within cells are arranged to easily facilitate all operations.

- Just-in-time (JIT): A system where a customer initiates demand and demand is then transmitted backward from the final assembly all the way to raw material, thus 'pulling' all requirements just when they are required.

- Kanbans: A signalling system for implementing JIT production.

- Total preventive maintenance (TPM). Workers carry out regular equipment maintenance to detect any anomalies. The focus is changed from fixing breakdowns to preventing them. Since operators are the closest to the machines, they are included in maintenance and monitoring activities in order to prevent and provide warning of malfunctions.

- Setup time reduction: Continuously try to reduce the setup time on the machine.

- Total quality management (TQM): A system of continuous improvement employing participative management that is centered on the needs of customers. Key components are employee involvement and training, problem-solving teams, statistical methods, long-term goals, and recognition that inefficiencies are produced by the system, not people.

- 5S: Focuses on effective work place organization and standardized work procedures.

- Pull scheduling: In a lean manufacturing system, material is scheduled through a pull system. The starting point for manufacture in a pull system is a customer order, which goes to final assembly that orders parts from the upstream manufacturing process. Two prerequisites for implementing pull scheduling are to reduce batch sizes and to manufacture fault-free parts.

- Takt time: It refers to the rate at which customers are buying products from the production line. It is calculated by dividing the total available time per day by the daily customer demand.

Value stream mapping (VSM) is a powerful tool for process definition. Value stream maps are used early in a kaizen or continuous improvement event to understand a process and aid in its redesign. 
Based on a synthesis of literature review the following crucial areas about 'lean' were identified and studied in detail: value concept, value stream mapping (VSM), kanban, flow, waste elimination, maintenance, customers, JIT, employee cooperation, development of excellent suppliers and lean design.

\section{Research methodology}

For the proposed problem consideration survey research methodology was used. Theory testing survey research is a long process which presupposes the pre-existence of a theoretical model or a conceptual framework. It includes a number of related sub-processes: the process of reshaping the theoretical domain into the empirical domain; the design and pilot testing processes; the process of collecting data for theory testing; the data analysis process; and the process of interpreting the results and writing the report.

Regarding the presented research process all stated phases were considered. The research was divided into three phases:

i. a wide-ranging analysis was conducted, of the existent literature aimed at determining the major dimensions of lean manufacturing;

ii. a questionnaire was designed, in order to investigate the real lean manufacturing, pre-tested on experts and pilot-firms (as suggested by Dillman, 1978), and later sent by post to the General and Plant/Production Managers responsible or participating in the lean project. This questionnaire contained 65 items, designed according to the Likert scales (a five- point Likert scale (Rossi et al., 1983) was used, ranging from 'strongly disagree' to 'strongly agree');

iii. the resulting data was subjected to reliability and validity analyses, and then analysed using uni- and multi-variate statistical techniques.

The research was carried out in 387 Slovenian companies within the mechanical and the electro-mechanical and electronic industries. The response rate was very good for the post-contact methodology. From the 387 (463 sent, 77 rejected) sent questionnaires, 72 (or 18,6 \%) were responded, all showing the firms' interest about lean. The subsequent statistical analysis was, therefore, carried out on the results of 72 companies which returned the questionnaires correctly filled in.

Measurement quality is usually assessed by survey reliability and validity. Since variables were developed for the first time the only suitable method for reliability verification is Cronbach's $\alpha$. According to Nunnally (Nunnally \& Bernstein, 1994) new variables can be accepted if $\alpha \geq 0,6$. Recommended value for $\alpha$ is 0,7 and with $\alpha$ grater than 0,8 the measure is very reliable. An internal consistency (reliability) analysis was performed using the SPSS programme package for the items of each critical dimension of lean manufacturing. With first calculation some dimensions didn't reach prescribed value 0,6 therefore some items were eliminated from the analysis. The table 1 shows critical dimensions of Lean Manufacturing (LM) with calculated Crombach $\alpha$. 
Vujica Herzog, N. \& Buchmeister, B.: Lean Manufacturing in Slovenian Compani...

\begin{tabular}{|c|c|c|c|}
\hline $\begin{array}{l}\text { Dimensions of Lean } \\
\text { Manufacturing }\end{array}$ & $\begin{array}{l}\text { Nr. of } \\
\text { items }\end{array}$ & Cronbach $\alpha$ & Cronbach $\alpha^{*}$ \\
\hline The value concept & 6 & 0,02 & - \\
\hline Value stream mapping (VSM) & $5(4)^{*}$ & 0,48 & $\mathbf{0 , 6 9 1}$ (without 9) \\
\hline Pull / kanban & $5(4)^{*}$ & 0,388 & $\mathbf{0 , 5 9 9}$ (without 13) \\
\hline Manufacturing flow & $6(5)^{*}$ & 0,485 & $\mathbf{0 , 6 4 0}$ (without 18 ) \\
\hline Waste elimination & 7 & $\mathbf{0 , 7 6 0}$ & \\
\hline Productive maintenance & $5(4) *$ & 0,402 & $\mathbf{0 , 6 7 0}$ (without 33) \\
\hline Customers & 5 & 0,342 & - \\
\hline JIT & $6(5) *$ & 0,569 & $\mathbf{0 , 6 6 7}$ (without 41) \\
\hline Employee involvement & 7 & $\mathbf{0 , 8}$ & \\
\hline Lean suppliers & $7(4) *$ & 0,354 & $\begin{array}{c}\mathbf{0 , 6 4 2} \\
\text { (without } 54,57,58 \text { ) }\end{array}$ \\
\hline
\end{tabular}

Tab. 1. Reliability analysis results for the critical dimensions of Lean Manufacturing $(\mathrm{LM})(*$ Recalculated Cronbach $\alpha)$

\section{Results of Descriptive Statistics with Discussion}

Table 2 contains all the new variables regarding lean manufacturing, explained by:

- the mean value of each variable,

- the standard deviation, and

- the coefficient of variation (CV), defined as the ratio between standard deviation and the mean values of each variable.

\begin{tabular}{|c|l|c|c|c|}
\hline $\mathbf{N r}$ & Variables for value concept & Mean & $\begin{array}{l}\text { St. } \\
\text { Dev. }\end{array}$ & $\begin{array}{l}\text { CV } \\
{[\%]}\end{array}$ \\
\hline 1. & $\begin{array}{l}\text { The value of a product can be measured in terms of } \\
\text { customer satisfaction }\end{array}$ & 4,18 & 0,861 & 20,6 \\
\hline 2. & $\begin{array}{l}\text { Higher product quality causes higher customer } \\
\text { satisfaction }\end{array}$ & 4,56 & 0,785 & 17,2 \\
\hline 3. & $\begin{array}{l}\text { The ratio between quality and costs does not essentially } \\
\text { influence customer satisfaction }\end{array}$ & 2,72 & 1,165 & 42,8 \\
\hline 4. & $\begin{array}{l}\text { The benefit of a product can be defined as its ability to } \\
\text { fulfil the customer's demands }\end{array}$ & 4,29 & 0,830 & 19,3 \\
\hline 5. & $\begin{array}{l}\text { The value of a product does not depend on benefit for the } \\
\text { customer }\end{array}$ & 2,68 & 1,330 & 49,6 \\
\hline 6. & $\begin{array}{l}\text { The benefit of a product depends on product attributes } \\
\text { and applicability }\end{array}$ & 4,04 & 1,027 & 25,4 \\
\hline
\end{tabular}

Tab. 2. Descriptive statistics results for 'value concept'

According to the survey research results respondents were very unanimous with the following claim about the value concept: 'higher product quality causes higher customer satisfaction' (Table 2, mean 4,56 and CV 17,2). According to the coefficient of variation value can be assessed that most of the respondents attributed the same importance, except two negative claims where respondents' opinions are very different (very high coefficient of variation).

Similar results can be detected for all other parts of questionnaire. Where the coefficient of variation is too high (recommended value for $\mathrm{CV}$ is 20), respondent 
opinions are different. Different opinions are probably caused by different approaches in companies, different education systems and different terminology.

\begin{tabular}{|c|l|c|c|c|}
\hline Nr. & Variables for value stream mapping & Mean & St. Dev. & $\begin{array}{c}\boldsymbol{C V} \\
{[\%]}\end{array}$ \\
\hline 7. & $\begin{array}{l}\text { Process mapping enables an accurate review of the } \\
\text { company's present state } \\
\text { Waste can be found and eliminated only if we know our } \\
\text { processes (mapping) }\end{array}$ & $3,92,39$ & 0,852 & 21,7 \\
9. & $\begin{array}{l}\text { We don't need any tools for waste-assessment - our } \\
\text { processes run without any waste } \\
\text { Exact process draft is fundamental for eventual } \\
\text { improvement assessment } 1,61\end{array}$ & 0,797 & 49,9 \\
11. $\begin{array}{l}\text { Process mapping is a very convenient method for possible } \\
\text { cost-reduction assessment and new investment } \\
\text { justification }\end{array}$ & 0,746 & 16,8 \\
\hline
\end{tabular}

Tab. 3. Descriptive statistics results for 'value stream mapping'

\begin{tabular}{|c|l|c|c|c|}
\hline Nr. & Variables for Kanban & Mean & St. Dev. & CV [\%] \\
\hline 12. & $\begin{array}{l}\text { Early search for information about customer needs and } \\
\text { demands enables the company to wholly meet customers } \\
\text { demands }\end{array}$ & 4,49 & 0,628 & 13,9 \\
13. & $\begin{array}{l}\text { Our customers don't know what they really want, for this } \\
\text { reason we offer them a product that could be interesting } \\
\text { for them in our judgment } \\
\text { Customer cooperation in the early stages of a new } \\
\text { product's development and design facilitates meeting } \\
\text { customers demands }\end{array}$ & 2,93 & 1,260 & 43,1 \\
15. & $\begin{array}{l}\text { Better response to customer needs and demands creates } \\
\text { satisfied customers and enables long-term cooperation } \\
\text { Early information on customer needs and demands } \\
\text { enables the company to reach greater effectiveness of } \\
\text { manufacturing }\end{array}$ & 4,76 & 0,435 & 11,5 \\
\hline
\end{tabular}

Tab. 4. Descriptive statistics results for 'Kanban'

As shown in Table 3, on average, mapping and exact process draft were identified as the two most important variables for value stream mapping. This ascertainment also confirms very low CV (18,9\% for mapping and 16,8\% for exact process draft), explaining that managers responsible or participating in lean project at their company share unique opinions about the importance of the two before mentioned variables. It is interesting that the higher coefficient of variation can be noticed in negative claim nr. 9 similarly as for kanban, negative claim nr. 13: 'Our customers don't know what they really want, for this reason we offer them a product that could be interesting for them in our judgment' (Table 3 and 4).

In the questionnaire part according 'flow' respondents were very unanimous with claim nr. 20: 'Effective production planning and control can prevent material shortages and late deliveries ' (Table 5). Descriptive statistics results for 'waste elimination' (Table 6) are very unanimous, similarly as for 'maintenance' (Table 7) where only greater deviation by claim nr. 33 can be observed: 'The defect number and scrap level don't essentially influence manufacturing quality'. 
Vujica Herzog, N. \& Buchmeister, B.: Lean Manufacturing in Slovenian Compani...

\begin{tabular}{|c|l|c|c|c|}
\hline Nr. & Variables for Flow & Mean & St. Dev. & $\begin{array}{l}\text { CV } \\
\text { [\%] }\end{array}$ \\
\hline 17. & $\begin{array}{l}\text { Manufacturing cells can greatly shorten time and } \\
\text { transport costs } \\
\text { Equipment layout is not of great importance for }\end{array}$ & 4,03 & 0,839 & 20,8 \\
19. & $\begin{array}{l}\text { manufacturing and transport time } \\
\text { Parts standardization and modular products shorten } \\
\text { manufacturing time } \\
\text { Effective production planning and control can prevent } \\
\text { material shortages and late deliveries }\end{array}$ & 4,90 & 1,128 & 59,4 \\
21. & $\begin{array}{l}\text { Effective long-term planning and control enables } \\
\text { optimal use of capacities with minimal costs whilst } \\
\text { satisfying demand and policy requirements. }\end{array}$ & 4,50 & 0,884 & 20,8 \\
22. $\begin{array}{l}\text { Aaily schedule or short-term planning can greatly } \\
\text { contribute to continuous flow by using overtime work, } \\
\text { subcontracting production, hiring additional workers, or } \\
\text { even adding entire work shifts. }\end{array}$ & 3,94 & 1,086 & $13,9,5$ \\
\hline
\end{tabular}

Tab. 5. Descriptive statistics results for 'Flow'

Descriptive statistics results for 'customers' (Table 7) differentiate again by negative claim nr. 38. Similarly for 'JIT' (Table 8) greater deviations by claim nr. 41 can be noticed.

\begin{tabular}{|c|c|c|c|c|}
\hline$\overline{N r}$. & Variables for Waste elimination & Mean & St. Dev. & $\begin{array}{l}\mathrm{CV} \\
{[\%]}\end{array}$ \\
\hline 23. & $\begin{array}{l}\text { A good inventory management system can greatly } \\
\text { reduce the necessary amount of material in stock }\end{array}$ & 4,43 & 0,747 & 16,8 \\
\hline 24. & $\begin{array}{l}\text { In a well-ordered warehouse, where shelves for } \\
\text { material (with pallets and bins) are labelled and have } \\
\text { permanent warehouse location, work is easier and } \\
\text { without dispensable waiting }\end{array}$ & 4,33 & 0,751 & 17,3 \\
\hline 25. & $\begin{array}{l}\text { With a good labelling system we can computerize the } \\
\text { warehouse and so we can, at any time, check the } \\
\text { material location and the inventory level }\end{array}$ & 4,61 & 0,618 & 13,4 \\
\hline 26. & $\begin{array}{l}\text { Vertical storage using a hoist for quick retrieval is very } \\
\text { applicable because we can save a great amount of } \\
\text { material on a smaller surface }\end{array}$ & 4,32 & 0,802 & 18,5 \\
\hline 27. & $\begin{array}{l}\text { Attention given to the short-time exchange to die bears } \\
\text { greatly on the time/cost of an individual product }\end{array}$ & 4,46 & 0,627 & 14,0 \\
\hline 28. & $\begin{array}{l}\text { Good machine capacity utilization and shorter } \\
\text { exchange times to die can reduce manufacturing costs } \\
\text { greatly }\end{array}$ & 4,54 & 0,649 & 14,3 \\
\hline 29. & $\begin{array}{l}\text { Permanent changes in customer demands and working } \\
\text { conditions require continuous search for improvements } \\
\text { and waste elimination at work }\end{array}$ & 4,51 & 0,712 & 15,7 \\
\hline
\end{tabular}

Tab. 6. Descriptive statistics results for 'Waste elimination' 


\begin{tabular}{|l|l|c|c|c|}
\hline Nr. & Variables for maintenance & Mean & $\begin{array}{c}\text { St. } \\
\text { Dev. }\end{array}$ & $\begin{array}{c}\text { CV } \\
\text { [\%] }\end{array}$ \\
\hline 30. & $\begin{array}{l}\text { Machine reliability can be assured by total preventive } \\
\text { maintenance }\end{array}$ & 4,47 & 0,731 & 16,3 \\
31. & $\begin{array}{l}\text { With total preventive maintenance, scrap sheets and } \\
\text { repair records the amount of damage can be reduced to } \\
\text { the minimum }\end{array}$ & 4,22 & 0,791 & 18,7 \\
32. & $\begin{array}{l}\text { Part of the time when machines don't work because of } \\
\text { damage should be as short as possible }\end{array}$ & 4,83 & 0,504 & 10,4 \\
33. & $\begin{array}{l}\text { The defect number and scrap level don't essentially } \\
\text { influence manufacturing quality }\end{array}$ & 1,61 & 0,987 & 61,1 \\
34. & $\begin{array}{l}\text { Part of scrap and rework regarding sale is an important } \\
\text { indicator of lean manufacturing state }\end{array}$ & 4,21 & 0,821 & 19,3 \\
\hline
\end{tabular}

Tab. 7. Descriptive statistics results for 'maintenance'

\begin{tabular}{|c|c|c|c|c|}
\hline$N r$. & Variables for customers & Mean & $\begin{array}{c}\text { St. } \\
\text { Dev. }\end{array}$ & $\begin{array}{l}\mathrm{CV} \\
{[\%]}\end{array}$ \\
\hline 35. & $\begin{array}{l}\text { Product quality is a basic condition for customer } \\
\text { satisfaction }\end{array}$ & 4,53 & 0,627 & 13,8 \\
\hline 36. & $\begin{array}{l}\text { Warranties put into force and the greater number of } \\
\text { customer complaints indicate that our quality is inferior }\end{array}$ & 4,21 & 1,006 & 23,8 \\
\hline 37. & $\begin{array}{l}\text { The most important thing is that our processes work as } \\
\text { reliably as possible and with the lowest possible level } \\
\text { of defects and scrap - we will find customers for our } \\
\text { products without any problems }\end{array}$ & 3,33 & 1,289 & 38,7 \\
\hline 38. & $\begin{array}{l}\text { Quality when perceiving customer needs and demands is } \\
\text { essential for a company's existence }\end{array}$ & 4,46 & 0,730 & 16,4 \\
\hline 39. & $\begin{array}{l}\text { Small lot sizes enables flexible responses to customers' } \\
\text { demands }\end{array}$ & 3,93 & 0,969 & 24,6 \\
\hline
\end{tabular}

Tab. 8. Descriptive statistics results for 'customers'

According to the survey research results respondents were very unanimous (mean value and low CV) about 'customers cooperation' (Table 10).

\begin{tabular}{|c|c|c|c|c|}
\hline$N r$. & Variables for JIT & Mean & St.Dev. & $\begin{array}{l}C V \\
{[\%]}\end{array}$ \\
\hline 40. & \begin{tabular}{|llllll}
$\begin{array}{l}\text { Regular and } \\
\text { manufacturing }\end{array}$ & on time deliveries ensure fluent & & & & \\
\end{tabular} & 4,49 & 0,787 & 17,5 \\
\hline 41. & $\begin{array}{l}\text { Material deliveries are never entirely exact, for this } \\
\text { reason we always have a slightly more material in stock } \\
\text { than necessary }\end{array}$ & 3,00 & 1,101 & 36,7 \\
\hline 42. & $\begin{array}{l}\text { Good cooperation with suppliers and their early } \\
\text { incorporation at the planning stage ensure us regular and } \\
\text { accurate deliveries }\end{array}$ & 4,39 & 0,723 & 16,5 \\
\hline 43. & $\begin{array}{l}\text { Most savings on time and costs can be reach by } \\
\text { shortening order-to-delivery times }\end{array}$ & 3,83 & 0,979 & 25,5 \\
\hline
\end{tabular}


Vujica Herzog, N. \& Buchmeister, B.: Lean Manufacturing in Slovenian Compani...

\begin{tabular}{|c|c|c|c|}
\hline $\begin{array}{l}\text { Reduced number of parts minimizes the opportunity for } \\
\text { defective parts or an assembly error and improves the } \\
\text { chance to automate the process. }\end{array}$ & 3,97 & 0,934 & 23,5 \\
\hline $\begin{array}{l}\text { Order and cleanliness during manufacturing essentially } \\
\text { influences an employee's mood and satisfaction }\end{array}$ & 4.43 & 0,819 & \\
\hline
\end{tabular}

Tab. 9. Descriptive statistics results for 'JIT'

Similar situation can be noticed by development of excellent suppliers (Table 11), where opinions differentiate at claims nr. 57 and 58. Descriptive statistics results for 'lean design' (Table 11) are very unanimous.

\begin{tabular}{|c|c|c|c|c|}
\hline$N r$. & Variables for customers cooperation & Mean & St. Dev. & $\begin{array}{l}\mathrm{CV} \\
{[\%]}\end{array}$ \\
\hline 46. & $\begin{array}{l}\text { Continuous process improvement within the company } \\
\text { can only be reached with the active cooperation of all } \\
\text { employees and the support of top management }\end{array}$ & 4,67 & 0,650 & 13,9 \\
\hline 47. & $\begin{array}{l}\text { Employee awarding for given improvement suggestions } \\
\text { is the best motivator for further cooperation }\end{array}$ & 4,18 & 0,793 & 18,9 \\
\hline 48. & $\begin{array}{l}\text { Public announced improvement suggestions and their } \\
\text { usefulness stimulate positive relations and employees } \\
\text { cooperation }\end{array}$ & 4,15 & 0,850 & 20,4 \\
\hline 49. & $\begin{array}{l}\text { The number of given improvements indicate the state of } \\
\text { employee preparedness for cooperation }\end{array}$ & 4,35 & 0,675 & 15,5 \\
\hline 50. & $\begin{array}{l}\text { Training about the role of cooperation and preparedness } \\
\text { to changes, is an essential element for success }\end{array}$ & 4,18 & 0,678 & 16,2 \\
\hline 51. & $\begin{array}{l}\text { Autonomy of the team, responsible for change } \\
\text { performance enables effective group problem solving }\end{array}$ & 4,18 & 0,775 & 18,5 \\
\hline 52. & $\begin{array}{l}\text { Cross-functional teams can manage and control business } \\
\text { processes according to the logical performance } \\
\text { sequences, independent of the department boundaries. }\end{array}$ & 3,79 & 0,948 & 25,0 \\
\hline
\end{tabular}

Tab. 10. Descriptive statistics results for 'customers' cooperation'

\begin{tabular}{|c|l|c|c|c|}
\hline Nr. & Variables for development of excellent suppliers & Mean & St. Dev. & $\begin{array}{c}\text { CV } \\
\text { [\%] }\end{array}$ \\
\hline 53. & $\begin{array}{l}\text { Regular and on-time deliveries are the main condition } \\
\text { for good cooperation }\end{array}$ & 4,19 & 0,685 & 16,3 \\
54. & $\begin{array}{l}\text { A company doesn't need a huge number of suppliers - } \\
\text { it's enough to have a few reliable suppliers }\end{array}$ & 3,81 & 1,016 & 26,7 \\
55. & $\begin{array}{l}\text { Cooperation with suppliers can be improved if they are } \\
\text { involved in product design and development phase yet }\end{array}$ & 4,44 & 0,603 & 13,6 \\
56. & $\begin{array}{l}\text { Long-term contracts with suppliers improves their } \\
\text { confidence by create a good working conditions } \\
\text { Market conditions are changing all the time so we can } \\
\text { also frequently change suppliers and easily find another } \\
\text { like it or even better }\end{array}$ & 4,46 & 0,604 & 13,5 \\
\hline
\end{tabular}


58. Quality today is a matter of fact, for this reason all the suppliers are equally good

59. A skilled and loyal supplier could be a key source of competitive advantage

\begin{tabular}{|l|l|l|}
1,63 & 0,740 & 45,4 \\
4,22 & 0,791 & 18,7 \\
\hline
\end{tabular}

Tab. 11. Descriptive statistics results for 'development of excellent suppliers'

\begin{tabular}{|c|c|c|c|c|}
\hline$N r$. & Variables for development of Lean design & Mean & $\begin{array}{c}\text { St. } \\
\text { Dev. }\end{array}$ & $\begin{array}{l}C V \\
{[\%]}\end{array}$ \\
\hline 60. & $\begin{array}{l}\text { The product design specifications always start from } \\
\text { customers' requirements and/or marketing research, } \\
\text { according to Quality Function Deployment (QFD). }\end{array}$ & 3,93 & 0,861 & 21,9 \\
\hline 61. & $\begin{array}{l}\text { We usually develop products using the 'house of } \\
\text { quality', deploying customers' needs into technical } \\
\text { specifications. }\end{array}$ & 3,53 & 1,074 & 30,4 \\
\hline 62. & $\begin{array}{l}\text { In every product development process we also do a } \\
\text { precise experimental plan. }\end{array}$ & 3,69 & 1,043 & 28,3 \\
\hline 63. & $\begin{array}{l}\text { We normally use Design of Experiments (DOE) to } \\
\text { approve products' technical specifications. }\end{array}$ & 3,21 & 1,113 & 34,6 \\
\hline 64. & $\begin{array}{l}\text { We always use the Failure Mode Effect Analysis } \\
\text { (FMEA) technique before launching a new product. }\end{array}$ & 3,65 & 1,077 & 29,5 \\
\hline 65. & $\begin{array}{l}\text { We consider a Priority Risk Number for each design } \\
\text { choice on products' part, and process operation. }\end{array}$ & 3,32 & 1,085 & 32,7 \\
\hline
\end{tabular}

Tab. 12. Descriptive statistics results for 'Lean design'

\section{Conclusions}

The performed research contributes to the area of operations management with detailed analysis of lean manufacturing variables supported with descriptive statistics. The scientific relevance of the research is mainly determined by what the research contribute to the existing literature. Review of the existing literature (Shah \& Ward; 2003, 2007; Womack \& Jones, 1996; Panizzolo, 1998; Sanchez \& Perez, 2001) shows that there is still a lot of issues relating to lean, which need to be addressed in the future. The basic problem is that there is still confusion between different concepts and terminology relating to lean. Presented paper tried to clarify the present confusion and using descriptive statistics results exposed the most important topics from lean that must be addressed in companies for effective lean implementation.

In the future another survey research about lean manufacturing would be interested to monitor progress and also the connections between different influent factors could be studied in detail.

\section{Acknowledgement}

The research was partly realized during the research visit in Udine enabled with University scholarship. The authors thank University of Udine for their support. 
Vujica Herzog, N. \& Buchmeister, B.: Lean Manufacturing in Slovenian Compani...

\section{References}

Dillman, D. A. (1978). Mail and Telephone Surveys: The Total Design Method, John Wiley \& Sons, New York

Dirgo, R. (2006). Look Forward, Beyond Lean and Six Sigma, J. Ross Publishing, Florida

Flynn, B. B., Schroeder, R. G. Sakakibara, S., 1994. A framework for quality management research and an associated measurement instrument. Journal of Operations Management, Vol. 11, Nr. 4, pp. 339-366

Hall, R. W. (1987). Attaining Manufacturing Excellence, Business One Irwin, Homewood, IL

Krafcik, J.F. (1998). Triumph of the lean production system, Sloan Management review, Vol. 30, No. 1, pp. 41-52

Motwani, J. (2003). A business process change framework for examining lean manufacturing: a case study, Industrial Management \& Data Systems, 103/5, 339346

Nicholas, J. (1998). Competitive Manufacturing Management: Continuous Improvement, Lean production, Customer - Focused Quality, Irwin/McGraw-Hill, New York, NY

Nunnally, J. C. in Bernstein, I. H. (1994). Psychometrics theory; Third edition; ISBN 007-047849-X, 1994

Ohno, T., (1988). Toyota Production System: Beyond Large Scale Production. Productivity Press, Cambridge, MA

Panizzolo, R. (1998). Applying the lessons learned from 27 lean manufacturers, International Journal of Production Economics, Vol. 55, pg. 223-240

Reddy B. S. P., Rao C. S. P. (2011). Flexible Manufacturing Systems Modelling and Performance Evaluation Using AutoMod. Int. Journal of Simulation Modelling, Vol. 10, No. 2, p. 78-90

Rossi, P. H., Wright, J. D., Anderson, A.B. (1983). Handbook of Survey Research, Academic Press, New York.

Sanchez, A. M., Perez, M. P., 2001. Lean indicators and manufacturing strategies. International Journal of Operations and Productions Management, Vol. 21, Nr. 11, pp. 1433- 1451

Shah, R., Ward, P.T., (2003). Lean manufacturing: context, practice bundles, and performance. Journal of Operations Management, Vol. 21, No. 2, pp.129-149.

Shah, R., Ward, P.T., (2007). Defining and developing measures of lean production. Journal of Operations Management, Vol. 25, pp.785-805

Sugimori, Y., Kunasoki, K., Cho, F.,_Uchikawa, S., (1977). Toyota Production System and Kanban System: materialization of just-in-time and respect-for-human system. International Journal of Production Research, Vol. 15, No. 6, pp. 553564

Vujica Herzog, N., Palcic, I., Polajnar, A. (2008). The state of the art in lean manufacturing, Chapter 80 in DAAAM International Scientific Book 2008, pp. 967-976, B. Katalinic (Ed.), Published by DAAAM International, ISBN 978-3901509-66-7, ISSN 1726-9687, Vienna, Austria

Womack, J. et al, (1990). The Machine that Changed the World, Rawson Associates, New York, NY

Womack, J. and Jones, D., (1996). Lean thinking: Banish Waste and Create Wealth in Your Corporation, Simon \& Schuster, New York, NY 